\title{
P03-013-B - Inaugural palate nodule of a systemic sarcoidosis
}

\author{
M Mael-Ainin ${ }^{1 *}$, M Bouaddi ${ }^{1}$, K El Morabite ${ }^{1}$, S Abil ${ }^{1}$, A Abdou${ }^{1}$, K Senouci ${ }^{2}$, B Hassam¹', I El Meknassi \\ From 7th Congress of International Society of Systemic Auto-Inflammatory Diseases (ISSAID) \\ Lausanne, Switerland. 22-26 May 2013
}

\section{Introduction}

Oral manifestations of the sarcoidosis are rare. We report a case of a systematic sarcoidosis revealed by a nodule of the palate.

\section{Objectives}

To emphasize on mucosa localization of sarcoidosis when addressing nodular lesion of the palate in order to allow an appropriate treatment.

\section{Methods}

Mrs M. L a 29-year-old woman, presented an isolated nodule of the soft palate. The nasofibroscopy was normal, the histology showed a non specific inflammatory infiltrate. Two years later, the patient presented papulonodular lesions of the face associated with anosmia and a second stage dyspnea of NYHA.

\section{Results}

Oral sarcoidosis is rare. Labial and lingual effects are at the forefront; effects of the palate remain exceptional. The lesions may take the form of a nodule, ulceration or perforation. Treatment based on systemic corticosteroids, sometimes with the addition of immunosuppressives or synthetic antimalarials.

\section{Conclusion}

Sarcoidosis of the soft palate is rare and probably underdiagnosed. The risk of perforation or occurrence of systemic localization requires a careful examination of the oral mucosa in all patients with sarcoidosis.

\section{Competing interests}

None Declared.

1Dermatologie - Vénérologie, Centre Hospitalier Universitaire ibn Sina, Morocco

Full list of author information is available at the end of the article

\section{Authors' details}

'Dermatologie - Vénérologie, Centre Hospitalier Universitaire ibn Sina, Morocco. ${ }^{2}$ Centre of Anatomic Pathology, United Nations, Rabat, Morocco.

Published: 8 November 2013

doi:10.1186/1546-0096-11-S1-A211

Cite this article as: Mael-Ainin et al:: P03-013-B - Inaugural palate nodule of a systemic sarcoidosis. Pediatric Rheumatology 2013 11(Suppl 1):A211.
Submit your next manuscript to BioMed Central and take full advantage of:

- Convenient online submission

- Thorough peer review

- No space constraints or color figure charges

- Immediate publication on acceptance

- Inclusion in PubMed, CAS, Scopus and Google Scholar

- Research which is freely available for redistribution

\section{() Biomed Central}

\section{Biomed Central}

